\author{
Research Article
}

\title{
PREPARATION AND PHYSICO CHEMICAL ANALYSIS OF A HERBOMINERAL REJUVENATIVE FORMULATION- LAKSHMI VILASA RASA
}

\begin{tabular}{|c|c|}
\hline holar, $2 \mathrm{P}$ & Rasa Sastra \\
\hline Article info & ABSTRACT \\
\hline Article History: & Lakshmi vilasa rasa (LVR) is a Kharaliya preparation mentioned in the Visha upavishadi \\
\hline-2021 & ngini indicated for Roga durbala deha, Krsa, Dehapushti, \\
\hline Revis & Vahnimandya, Lavanya vardhana etc. It consists of six ingredients namely Shoditha Parada, \\
\hline 021 & Shoditha Gandhaka, Loha Bhasma (LB), Shoditha Kupeelu, Shoditha Tankana and Maricha \\
\hline KEI & ed thrice in four Bhavana media. The current study sheds light on the methodology \\
\hline $\begin{array}{l}\text { Lakshmi vilasa rasa, } \\
\text { Rasa Tarangini, } \\
\text { Khalviya rasayana, } \\
\text { physicochemical } \\
\text { analysis. }\end{array}$ & $\begin{array}{l}\text { and results of the preparation and analytical study of Lakshmi vilasa rasa. The physico } \\
\text { chemical analysis of LVR revealed the following- pH } 8.76 \text {, Loss on drying } 10.94 \% \text {, Water } \\
\text { soluble extractive } 38 \% \text { and Alcohol soluble extractive } 0.89 \% \text {. Weight variation test of } \\
\text { Lakshmi vilasa rasa showed that the Gulikas were within the acceptable limit. Particle size } \\
\text { analysis (PSA) of LB was } 432.69 \mathrm{~nm} \text {. }\end{array}$ \\
\hline
\end{tabular}

\section{INTRODUCTION}

Ayurveda, a holistic science of medicine practiced and used by Indians for ages, is gaining popularity around the world. Ayurveda emphasizes the importance of healthy lifestyle, proper nutrition, and the use of medicines in the prevention and maintenance of health.

It can be observed in Ayurvedic literature that there are numerous formulations coming under the same name but with varying ingredients and indications. According to Bharatha Bhaishajya Ratnakara, an Ayurvedic formulations compilation textbook, there are seven types of Lakshmi vilasa rasa. Indications include Jwara, Rajayakshma, Rasayana, Vajeekarana, Siro roga, and others. Some of these compositions comprises of Kajjali, Abhraka, Swarna, Tara, Loha, Tamra, Haritala, Vanga, Mukta, as well as, Upavishas like Vijaya, Dhathura, and other herbal ingredients. The present work concentrates on one such formulation mentioned in Vishopavishadi vijnajiya taranga of Rasa Tarangini.[1]

\begin{tabular}{|l|l|l|}
\hline \multicolumn{3}{|c|}{ Access this article online } \\
\hline Quick Response Code & & $\begin{array}{l}\text { Published by Mahadev Publications (Regd.) } \\
\text { publication licensed under a Creative } \\
\text { Commons Atribution-NonCommercial- } \\
\text { ShareAlike 4.0 International (CC BY-NC-SA } \\
\text { 4.0) }\end{array}$ \\
\hline
\end{tabular}

The Rasa drugs are widely known for their attributes such as rapid effectiveness, a low dosage requirement, and a wide range of therapeutic utility. Rasa drugs can be classified into four types in Rasa Shastra: Kupipakwa Rasayana, Parpati Rasayana, Pottali Rasayana, and Khalviya Rasayana. Lakshmi vilasa rasa (LVR) is an Ayurvedic herbo mineral Khalviya rasayana mentioned in the Visha upavishadi Vijnaneeya Taranga of Rasa Tarangini indicated for Rogadurbaladeha, Krsa, Ksheenaretas, Dehapushti, Kama virya vardanam, Balya, Vrsya, Vahnimandya nashana, Raktasanchana and Lavanya vardhana. It consists of six ingredients namely Shoditha Parada, Shoditha Gandhaka, Loha Bhasma (LB), Shoditha Kupeelu, Shoditha Tankana and Maricha triturated in four Bhavana dravyas namely Ardraka swarasa, Satavari swarasa, Bhumyamalaki swarasa and Bhrngaraja swarasa. Bhavana is performed three times in each medium before being rolled into Gulikas of Ratti matra (125mg).

\section{MATERIALS AND METHODS}

\section{Preparation of Lakshmi vilasa rasa}

The herbal raw materials were procured from authentic sources and authenticated by Dravya guna expert, while the metal/minerals except Tankana were procured from a local laboratory supply store, Thiruvananthapuram. Tankana was procured from a local raw medicine store, Thiruvananthapuram and was certified by Rasa Shastra expert. The composition 
Int. J. Ayur. Pharma Research, 2021;9(12):11-18

of Lakshmi Vilas Rasa is provided in the Table 1 . The process involved following stages viz. purification of Parada, purification of Gandhaka, preparation of Kajjali, preparation of Loha Bhasma, purification of
Tankana, purification of Kupeelu bija, preparation of Maricha churna, preparation of Ardraka, Satavari, Bhumyamalaki and Bhrngaraja swarasas, Bhavana (levigation) with above mentioned Swarasas.

Table 1: Composition and Proportion of each Ingredient of LVR

\begin{tabular}{|l|l|l|c|}
\hline Ingredients & Scientific/Botanical name & Part/Form used & Proportion in text \\
\hline Kupeelu & Strychnosnux-vomica Linn & Shoditha (Purified) seeds & 6 \\
\hline Tankana & Borax & Shoditha (Purified) powder & 6 \\
\hline Maricha & Piper nigrum Linn & Fruit powder & 6 \\
\hline Loha & Ferric oxide & Bhasma /Incinerated iron & 4 \\
\hline Gandhaka & Sulphur & Shoditha (Purified) Sulphur & 2 \\
\hline Parada & Hydrargyrum & Shoditha (Purified) Mercury & 1 \\
\hline Ardraka & Zingiber officianale & Swarasa /Fresh juice extract & --- \\
\hline Satavari & Asparagus racemosus & Swarasa/Fresh juice extract & --- \\
\hline Bhumyamalaki & Phyllanthus niruri & Swarasa/Fresh juice extract & --- \\
\hline Bhrngaraja & Eclipta alba & Swarasa/Fresh juice extract & --- \\
\hline
\end{tabular}

\section{Purification of Parada ${ }^{2]}$}

Shodhana or purification of 200g of Parada was done by levigation in 3 media- Kumari swarasa, Chitraka kashaya and Kakamachi swarasa in a Khalwa yantra (mortar and pestle). Chitraka shodhana was carried out in Churnodaka prior to the preparation of Kashaya. [3]

Table 2: Parada Shodhana

\begin{tabular}{|l|l|l|l|l|}
\hline Shodhana medium & $\begin{array}{l}\text { Quantity of } \\
\text { Drava used }\end{array}$ & $\begin{array}{l}\text { Duration } \\
\text { of Bhavana }\end{array}$ & $\begin{array}{l}\text { Change in } \\
\text { weight (in gm) }\end{array}$ & $\begin{array}{l}\text { Loss of weight } \\
\text { (in gm) }\end{array}$ \\
\hline Kumari swarasa & $200 \mathrm{ml}$ & $8 \mathrm{hrs}$ & 196.68 & $3.32(1.66 \%)$ \\
\hline Chitraka kashaya & $150 \mathrm{ml}$ & $8 \mathrm{hrs}$ & 196.56 & $0.21(0.1 \%)$ \\
\hline Kakamachi swarasa & $200 \mathrm{ml}$ & $8 \mathrm{hrs}$ & 191.86 & $4.7(2.39 \%)$ \\
\hline
\end{tabular}

\section{Purification of Gandhaka ${ }^{[4]}$}

Gandhaka shodhana was done as per Kurmaputa method. 3L Cow's milk was taken in an earthen pot of 5L capacity smeared with ghee and covered with a cotton fabric. Using a spoon, 500gm fine Gandhaka powder was gently placed on the fabric. It was then wrapped three times in mud-smeared cloth and closed with an appropriately sized Sharava (earthen lid). The entire equipment was set in a ground trench and covered with 48 pieces of coconut husk. The husk was ignited and the temperature range as well as the peak temperature reached $\left(492^{\circ} \mathrm{C}\right)$ was recorded. The mud covers and Sharava were removed after attaining Swangaseetha (self-cooling), and the milk was drained to obtain Gandhaka globules. To eliminate the milk fat, it was rinsed thoroughly with warm water. Shodhitha Gandhaka was then shade dried, pulverised, and sieved through sieve no. 120.

Table 3: Gandhaka shodhana

\section{Preparation of Kajjali}

\begin{tabular}{|c|c|}
\hline Gandhaka before Shodhana & $500 \mathrm{~g}$ \\
\hline Gandhaka after Shodhana & $468 \mathrm{~g}(93.6 \%)$ \\
\hline Loss of weight & $32 \mathrm{~g}(6.4 \%)$ \\
\hline
\end{tabular}

In a mortar, one-part Shoditha parada was placed, and two parts Gandhaka was added gradually. Mardana (grinding) was carried out until Kajjali siddha lakshanas were achieved.

Table 4: Observation during grinding of Kajjali

\begin{tabular}{|c|c|}
\hline Quantity of Sh. Parada & $26.8 \mathrm{gm}$ \\
\hline Quantity of Sh. Gandhaka & $53.6 \mathrm{gm}$ \\
\hline No. of hours taken for grinding & 58 \\
\hline Weight of Kajjali obtained & $62 \mathrm{gm}(77.11 \%)$ \\
\hline Loss of weight & $18.4 \mathrm{gm}(22.88 \%)$ \\
\hline
\end{tabular}




\section{Table 5: Kajjali Siddha Lakshanas}

\begin{tabular}{|c|c|}
\hline Features & Time taken \\
\hline Krishna varna & $5 \mathrm{hr}$ \\
\hline Rekhapurna & $8 \mathrm{hr}$ \\
\hline Varitaratwa & $15 \mathrm{hr}$ \\
\hline Nischandratwa & $52 \mathrm{hr}$ \\
\hline - & \\
\hline
\end{tabular}

Fig No 1. Kajjali Preparation

\section{Preparation of Loha Bhasma}

Samanya and Vishesha shodhana are the two steps in Loha shodhana. ${ }^{[5,6]}$ Samanya shodhana of $1 \mathrm{~kg}$ Loha was carried out by Nirvapa (quenching) in five media- Taila, Takra [7], Go Mutra, Aranala [8] and Kulatha kashaya. [9] Shoditha Loha was subjected to Nirvapa in Triphala kashaya seven times during Vishesha shodhana. Loha marana (incineration) comprised of three phases: Bhanupaka, Sthalipaka and Putapaka. [10]

The procedure is referred to as Bhanupaka since the paka phase occurs in the presence of sunlight. Shoditha Loha was submerged in trays of Triphala kashaya and dried in the sun. The day after, freshly produced kashaya was used, and the process was repeated seven times in total. Loha was rinsed and dried after Bhanupaka.

Loha was subjected to Sthalipaka after Bhanupaka. Since the Paka occurs in a Sthali or Kadai, this procedure is referred to as Sthalipaka. Loha was taken in an iron Kadai and heated. Triphala kashaya was introduced to this and heated until all of the Kashaya boiled, reduced, and eventually dried. This process was carried out seven times.

Table 6: Loha Samanya and vishesha shodhana

\begin{tabular}{|l|c|c|c|c|l|}
\hline Name of medium & $\begin{array}{c}\text { Quantity } \\
\text { of } \\
\text { medium }\end{array}$ & $\begin{array}{c}\text { Quantity of } \\
\text { medium for } \\
\text { each Nirvapa }\end{array}$ & $\begin{array}{c}\text { Weight of Loha } \\
\text { before } \\
\text { Shodhana (gm) }\end{array}$ & $\begin{array}{c}\text { Weight of Loha } \\
\text { after Shodhana } \\
\text { (gm) }\end{array}$ & Colour of Loha \\
\hline Taila & 7L & 1L & 1000 & 1114 & Black \\
\hline Takra & 7L & 1L & 1114 & 1011 & $\begin{array}{l}\text { Black with some } \\
\text { red aggregates }\end{array}$ \\
\hline Go mutra & 7L & 1L & 1011 & 998.5 & Reddish black \\
\hline Aranala & 7L & 1L & 998.5 & 993.5 & Brownish black \\
\hline Kulatha kashaya & 7L & 1L & 993.5 & 984 & Dull black \\
\hline Triphala kashaya & 7L & 1L & 984 & 979 & Black \\
\hline
\end{tabular}

Table 7: Loha Bhanupaka and Sthalipaka

\begin{tabular}{|l|l|l|l|l|l|l|}
\hline $\begin{array}{l}\text { Name of } \\
\text { procedure }\end{array}$ & Name of medium & $\begin{array}{l}\text { Quantity of } \\
\text { medium for } \\
\text { each process }\end{array}$ & $\begin{array}{l}\text { Quantity of } \\
\text { medium in } \\
\text { total }\end{array}$ & $\begin{array}{l}\text { Weight of } \\
\text { loha before } \\
\text { (gm) }\end{array}$ & $\begin{array}{l}\text { Weight of } \\
\text { loha } \text { after } \\
\text { (gm) }\end{array}$ & $\begin{array}{l}\text { Colour } \\
\text { of loha }\end{array}$ \\
\hline Bhanupaka & Triphala kashaya & $490 \mathrm{ml}$ & $3.43 \mathrm{~L}$ & $979 \mathrm{~g}$ & $1206 \mathrm{~g}$ & Black \\
\hline Sthalipaka & Triphala kashaya & $1.03 \mathrm{~L}$ & $7.2 \mathrm{~L}$ & $1206 \mathrm{~g}$ & $1572 \mathrm{~g}$ & Black \\
\hline
\end{tabular}

After Sthalipaka, the Loha bhavana was done in Triphala kashaya until Samyak bhavita lakshanas were obtained. Loha was then shaped into Chakrikas (pellets), dried, and placed on appropriately sized Sharava, 
Int. J. Ayur. Pharma Research, 2021;9(12):11-18

followed by wrapping 7 times in mud smeared cloth (Sandhi bandhana). The Sharava was placed in an electric muffle furnace and heated to $700^{\circ} \mathrm{C}$ for one hour. After the Sharava cooled down, the Sandhi bandhana was removed, the Bhasma was collected and the entire process was repeated. Temperature was increased to $800^{\circ} \mathrm{C}$ for Puta 6,7,8,9 and maintained for 1 hour until ideal Bhasma lakshanas were obtained.

Graph 1. Loha marana in EMF at $700^{\circ} \mathrm{C}$

\section{Temperature pattern}

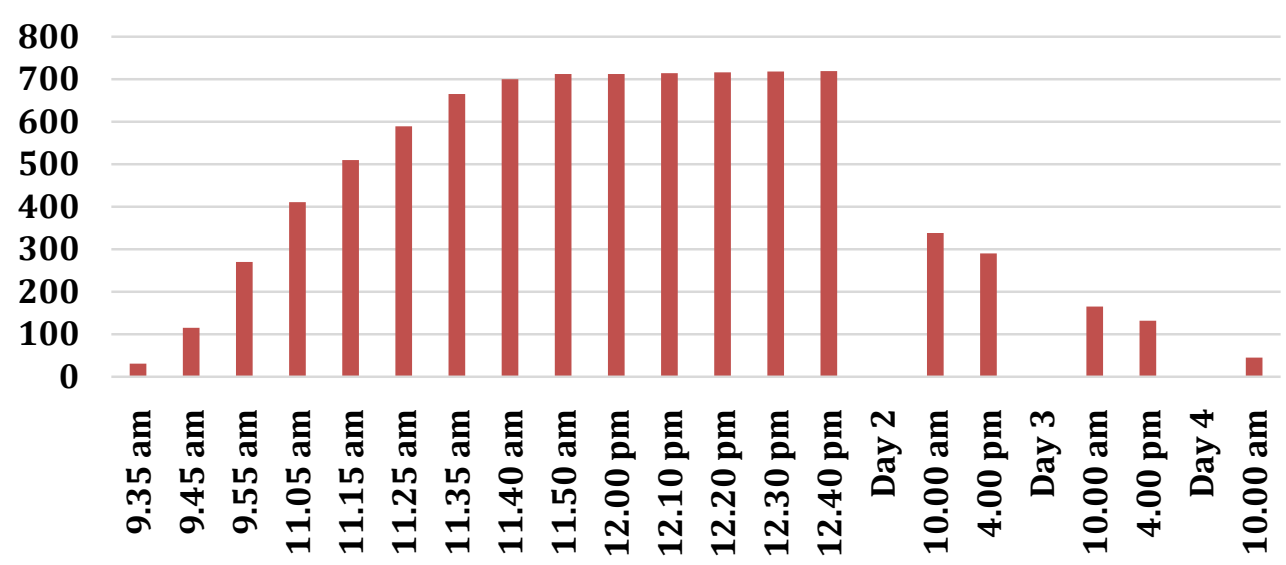

Table 8: Loha marana

\begin{tabular}{|l|l|l|l|l|l|}
\hline Puta No & $\begin{array}{l}\text { Initial } \\
\text { weight in gm }\end{array}$ & $\begin{array}{l}\text { Amount of Triphala } \\
\text { kashaya in ml }\end{array}$ & $\begin{array}{l}\text { Weight before } \\
\text { Puta in gm }\end{array}$ & $\begin{array}{l}\text { Weight after } \\
\text { Puta in gm }\end{array}$ & $\begin{array}{l}\text { Change in } \\
\text { weight in gm }\end{array}$ \\
\hline 1 & 625 & 200 & 577 & 420 & 157 \\
\hline 2 & 420 & 200 & 450 & 400 & 50 \\
\hline 3 & 400 & 150 & 413 & 385.5 & 27.5 \\
\hline 4 & 385.5 & 140 & 397.5 & 377.5 & 20 \\
\hline 5 & 377.5 & 110 & 392.5 & 381 & 11.5 \\
\hline 6 & 381 & 100 & 381 & 372.5 & 8.5 \\
\hline 7 & 372.5 & 130 & 405.5 & 378.5 & 27 \\
\hline 8 & 378.5 & 120 & 394.5 & 377 & 17.5 \\
\hline 9 & 377 & 150 & 410 & 378 & 32 \\
\hline
\end{tabular}

Table 9: Bhasma pareeksha of Loha Bhasma

\begin{tabular}{|l|l|}
\hline Varna & Pakva jambu \\
\hline Varitaratwa & Present \\
\hline Rekhapurnatva & Present \\
\hline
\end{tabular}

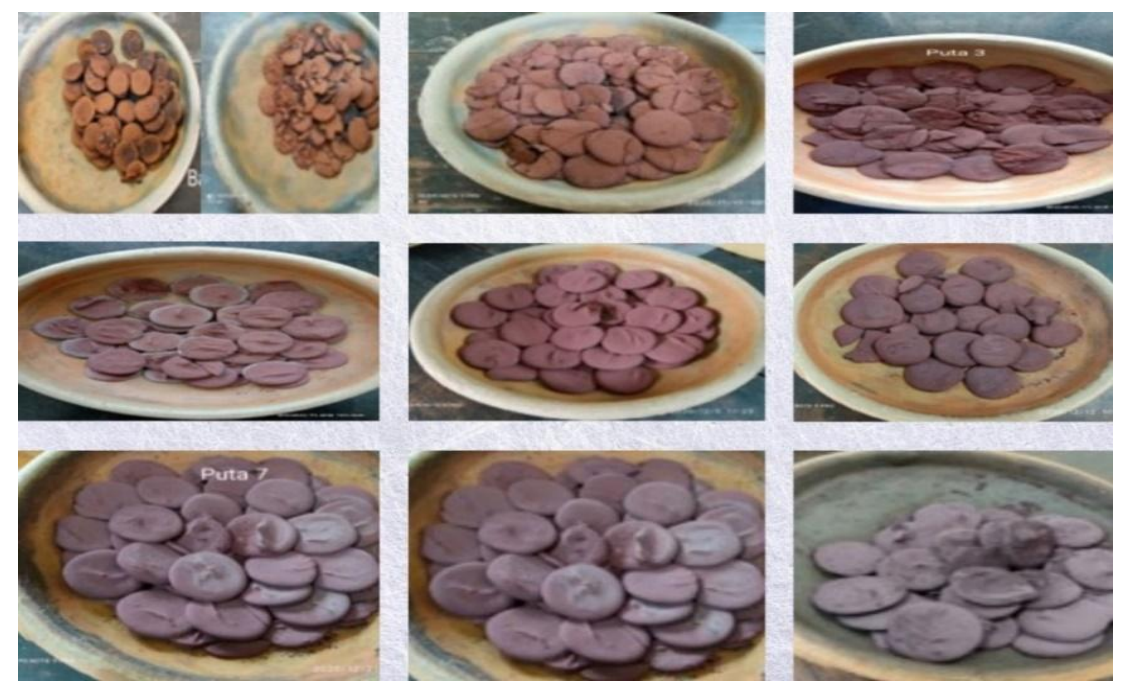

Fig 2. Loha marana 


\section{Purification of Tankana ${ }^{[11]}$}

500g Tankana was finely ground using a Khalwa yantra, then placed in a bronze vessel and heated till it lost its water content and became light and fluffy. 286gm Shoditha tankana was obtained.

\section{Purification of Kupeelu bija ${ }^{[12]}$}

Shodhana of 500g Kupeelu was performed in Dola yantra with milk for one Yama (3 hours). Following Shodhana, Kupeelu became soft and flexible, having a rubbery texture. It was rinsed in hot water immediately after Shodhana and the skin was peeled. Later, it was split in half to extract the cotyledon inside. This was fried in a bronze vessel with small amount of ghee until the Kupeelu turned brown and brittle. After cooling, it was ground using a pulverizer, sieved, and weighed.

\section{Preparation of Maricha churna}

Maricha was obtained from a reliable source and authenticated. 240g Maricha was pulverized, and 185g was obtained after sieving.

\section{Preparation of Bhavana Swarasas}

Before extracting Swarasa, Ardraka was cleaned, peeled, and diced in batches. The extraction of Satavari moola swarasa involved peeling the outer skin, removing the internal vein, slicing into smaller pieces, and grinding. Swarasa was extracted from Bhumyamalaki and Bhrngaraja after thorough washing and chopping. To avoid deterioration, the Swarasas were extracted a day prior to the Bhavana and preserved in the freezer.

\section{Preparation of final drug}

Lakshmi vilasa rasa is a formulation containing 6 ingredients and Bhavana in 4 mediums 3 times each.

Table 10: Ingredients and its quantity taken of Lakshmi Vilasa Rasa

\begin{tabular}{|l|l|l|}
\hline Drug & Ratio as per reference & Quantity \\
\hline Kajjali (Hg: S = 1:2) & 3 Tola & $62 \mathrm{gm}$ \\
\hline Loha bhasma & 4 Tola & $83 \mathrm{gm}$ \\
\hline Maricha churna & 6 Tola & $124 \mathrm{gm}$ \\
\hline Shudha Tankana churna & 6 Tola & $124 \mathrm{gm}$ \\
\hline Shudha Kupeelu churna & 6 Tola & $124 \mathrm{gm}$ \\
\hline Ardraka swarasa & $-----\cdot----$ & $1350 \mathrm{ml}$ \\
\hline Satavari swarasa & ---- & $1595 \mathrm{ml}$ \\
\hline Bhumyamalaki swarasa & ----------- & $1750 \mathrm{ml}$ \\
\hline Bhrngaraja swarasa & ----------- & $1300 \mathrm{ml}$ \\
\hline
\end{tabular}

Table 11: Bhavana dravyas of Lakshmi vilasa rasa

\begin{tabular}{|l|l|l|}
\hline Bhavana medium & $\begin{array}{l}\text { Weight of drug before } \\
\text { Bhavana }\end{array}$ & $\begin{array}{l}\text { Weight of drug after } \\
\text { Bhavana }\end{array}$ \\
\hline Ardraka swarasa & $517 \mathrm{gm}$ & $893.5 \mathrm{gm}$ \\
\hline Satavari swarasa, & $893.5 \mathrm{gm}$ & $836 \mathrm{gm}$ \\
\hline Bhumyamalaki swarasa & $836 \mathrm{gm}$ & $903 \mathrm{gm}$ \\
\hline Bhrngaraja swarasa. & $903 \mathrm{gm}$ & $1198 \mathrm{gm}$ \\
\hline
\end{tabular}
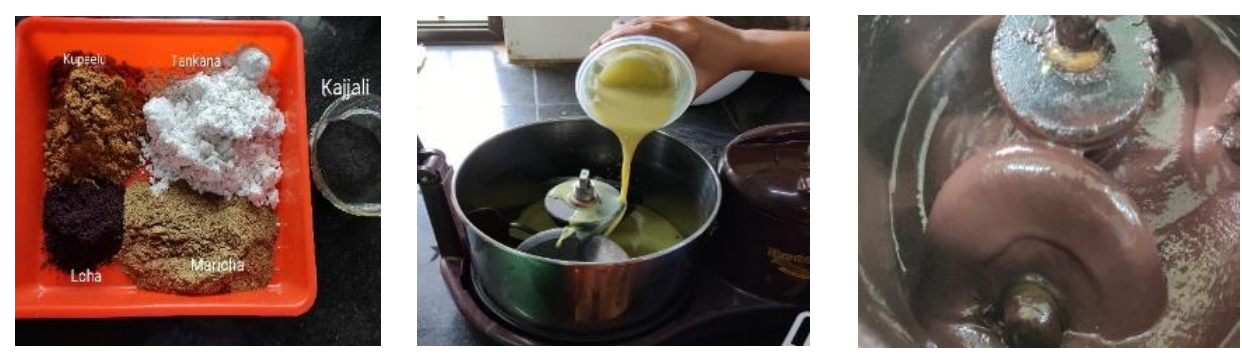

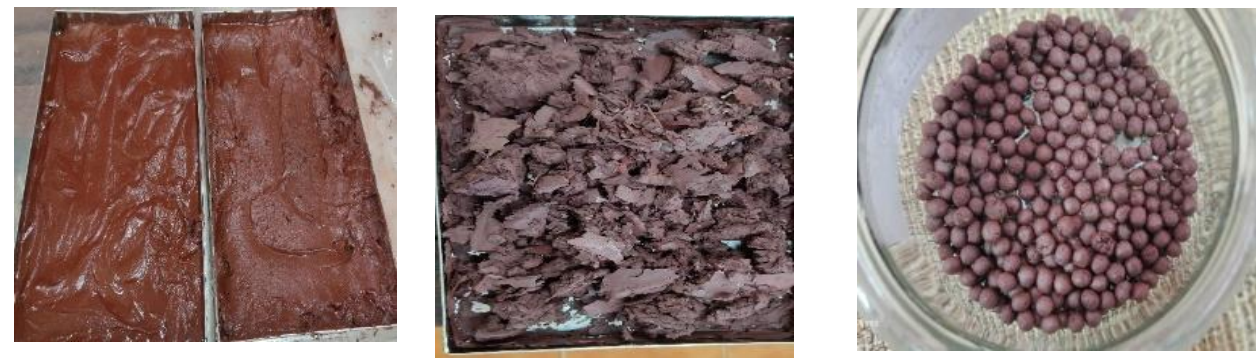

Fig 3. Preparation of Lakshmi Vilasa Rasa

\section{RESULTS}

Analytical Study of Lakshmi vilasa rasa involved 3 steps

a. Organoleptic Characteristics

b. Physico-Chemical analysis

c. Instrumental analysis

Organoleptic characters of Lakshmi vilasa rasa

Table 12: Organoleptic features of Lakshmi vilasa rasa

\begin{tabular}{|l|l|}
\hline Colour & Maroon \\
\hline Taste & Tikta, Katu \\
\hline Touch & Smooth, fine \\
\hline Smell & Characteristic \\
\hline
\end{tabular}

Physico chemical analysis of Lakshmi vilasa rasa

Table 13: Physico chemical analysis of Lakshmi vilasa rasa

\begin{tabular}{|l|l|}
\hline Parameters & Lakshmi vilasa rasa \\
\hline $\mathrm{pH}$ & 8.76 \\
\hline Loss on drying & $10.94 \%$ \\
\hline Water soluble extractive & $38 \%$ \\
\hline Alcohol soluble extractive & $0.89 \%$ \\
\hline
\end{tabular}

Weight variation test [13]

Weight Variation of Lakshmi vilasa rasa was calculated by

Weight Variation $=(I W-$ AW $) /$ AW X 100\%

IW: Individual weight, AW: Average weight

The average weight of 20 Gulikas were 0.1225

Table 14: Weight variation of Lakshmi Vilasa Rasa

\begin{tabular}{|l|l|l|l|}
\hline Individual weight (g) & \% Deviation & Individual weight (g) & \% Deviation \\
\hline 0.118 & 3.67 & 0.123 & 4 \\
\hline 0.127 & 0.4 & 0.129 & 5.30 \\
\hline 0.123 & 0.4 & 0.116 & 5.30 \\
\hline 0.128 & 4.4 & 0.133 & 8.5 \\
\hline 0.118 & 3.67 & 0.13 & 6.1 \\
\hline 0.120 & 2.04 & 0.125 & 2.04 \\
\hline 0.13 & 6.1 & 0.116 & 5.30 \\
\hline 0.117 & 4.48 & 0.118 & 3.67 \\
\hline 0.115 & 6.1 & 0.118 & 3.67 \\
\hline 0.128 & 4.4 & 0.116 & 5.30 \\
\hline
\end{tabular}

Only one individual weight deviated from $7.5 \%$ but it didn't deviate by more than twice the acceptable percentage $(15 \%)$ 


\section{Determination of Particle Size Analysis (PSA)}

The PSA of Loha bhasma was conducted at Council of Scientific and Industrial Research-National Institute for Interdisciplinary Science and Technology (CSIR-NIIST). Industrial estate. Pappanamcode. Thiruvananthapuram. Hydrodynamic diameter of final puta of Loha (puta 9) was $432.6969877 \mathrm{~nm}$.

\section{DISCUSSION}

The present study drug Lakshmi vilasa rasa is a Rasa Tarangini formulation referenced in the Visha upavishadi vijnaneeya taranga. Shudha Parada, Shudha gandhaka, Loha bhasma, Shudha Kupeelu churna, Shudha tankana, and Maricha churna are its ingredients. There are no accessible data regarding the preparation and analytical study of this formulation, hence the current study was carried out to bridge this knowledge gap.

The first step in the preparation of Lakshmi Vilasa rasa was Shodhana of Parada. 200gm Parada was levigated for 8 hours in Kumari swarasa, Chitraka kashaya, and Kakamachi swarasa, yielding a final weight of 191.86g. Since washing Parada after Bhavana with Kakamachi swarasa was difficult due to its sticky and slimy nature, the loss was primarily on the last Bhavana (2.39\%). The Kurmaputa method was used for Gandhaka shodhana. The entire process took about 5 hours, and the end result was Gandhaka globules weighing 468g after washing, drying, and powdering. Kajjali was prepared from the Parada and Gandhaka obtained after Shodhana. It was done in accordance to the ratio mentioned in the formulation: $1: 2$.

Loha bhasma preparation comprises of Shodhana and Marana of Loha. After Samanya and Vishesha shodhana it was observed that the initial $1 \mathrm{~kg}$ Loha was reduced to 979g. During Loha marana, the hardness of the Chakrikas increased after the fourth puta and the color became slightly purple. Since the classical Bhasma lakshanas such as Varitaratwa and Rekhapurnatwa were not obtained, the temperature was raised to $800^{\circ} \mathrm{C}$ for Puta $6,7,8,9$ and maintained for 1 hour. The color of Loha bhasma reached the target of Pakwajambu phala varna by the end of the 9th Puta. It also attained Varitaratwa and Rekhapurnatwa.

Tankana shodhana of 500gm Tankana was done in 5 batches of $100 \mathrm{gm}$ each. The entire process took approximately 16 hours. The absence of hissing sound, which could be indicative of loss of water of crystallization and fine Tankana particles escaping the vessel, was used to determine the endpoint. The weight loss was significant, as the final weight reached was $286 \mathrm{gm}$, a $40 \%$ drop.

$500 \mathrm{~g}$ Kupeelu shodhana was performed in Dola yantra with milk, as specified in Rasa Tarangini. A study on the effect of cow's milk for Shodhana of Kupeelu discovered that Shodhana in Go ksheera lowered the toxicity of its strychnine and brucine contents. [14] Shodhana took 1 Yama (3 hours) and used 8.5L of milk. Weight of Kupeelu decreased by 46.5 percent after Shodhana.

An increase in weight can be noted following Bhavana in Ardraka swarasas during the manufacture of the final drug, which could be influenced by the presence of starch content in Ardraka. When the drug reached a semi-solid consistency, it had to be removed from the grinder as grinding was no longer feasible. The drug was then shade dried and weighed before proceeding to the Bhavana in the next medium. Gulikas weighing $125 \mathrm{mg}$ were made. As a weight decrease was detected after shade drying, it was initially weighed at around 140 to $150 \mathrm{mg}$. The Gulikas were maroon in colour, with Tikta katu rasa and a distinct smell.

The physicochemical factors can be used to assess the purity and quality of a drug. In the current study, $\mathrm{pH}$, loss on drying, water soluble extractive value, and alcohol soluble extractive value for LVR were determined. The loss on drying value of Lakshmi vilasa rasa was $10.94 \%$. It can be assumed that the increased loss on drying in preparations containing mercury and sulphur might be due to the sublimation of the same and not due to moisture content of the drug. The water-soluble and alcohol-soluble extractive values reflect the quantity of active ingredient in a given amount of plant material when extracted with corresponding solvents. Water soluble extractive value of Lakshmi vilasa rasa was $38 \%$ and alcohol soluble extractive value was $0.89 \%$. Lakshmi vilasa rasa had a $\mathrm{pH}$ of 8.76. The basic $\mathrm{pH}$ of the gulika might be due to the presence of Shoditha Tankana as observed in a similar study.[15] Hydrodynamic diameter of LB was $432.69 \mathrm{~nm}$, according to PSA carried out at CSIR Pappanamcode which is well within the acceptable limit.

\section{CONCLUSION}

Lakshmi vilasa rasa mentioned in Rasa Tarangini, is a Yoga that, according to its constituents, has the capacity to be exceedingly potent as a Rasayana but has surprisingly remained unexplored. The preparation of Lakshmi vilasa rasa was in accordance with traditional pharmaceutical processes. The standards established in this study can undoubtedly be used as a valuable tool for standardization and quality assurance of this herbomineral composition.

\section{REFERENCES}

1. Shastri K. Rasatarangini of Sadananda Sharma. 8th ed. New Delhi: Motilal Banarasidas Publication; 2014; pg no 686 -687.

2. Suresh P, Dhannapuneni V. Rasendra Sara Sangrah of Sri Gopala Krishna Bhatt. 2nd ed. Varanasi: Chaukhamha Sanskrit Sansthan; 2012. pg no.13. 
3. Shastri K. Rasatarangini of Sadananda Sharma. 8th ed. New Delhi: Motilal Banarasidas Publication; 2014; pg no 753.

4. Sri Gulraj Sharma Misra. Ayurveda Prakasha. Varanasi; Chaukambha; 2009. pg no 261.

5. Satpute AD. Rasaratna samucchaya. New Delhi; chaukhambha Sanskrit prathishtan; 2010. pg no 110.

6. Sharma Sadananda. Rasa Tarangini. Edited By Pandit Kashinath Shastri. 8th Edition. Motilal Banarasidas Publication; New Delhi; pg no 464.

7. Sri Gangasahay Pandey. Bhava Prakasha Nighantu of Bhava mishra. Chaukhambha Bharati Academy, Varanasi; 2013; 755.

8. Sitaram Bulusu. Bhavaprakasha of Bhavamishra Vol 1; Varanasi: Chaukhambha Orientalia, 2012; pg no 546.

9. Murthy H. Sarangadhara samhita of Sarangadhara; Varanasi: Chowkhamba sanskrit series office; 2010.; pg no 111.

10. Shastri K. Rasatarangini of Sadananda Sharma. 8th ed. New Delhi: Motilal Banarasidas Publication; 2014; pg no 496-500.

\section{Cite this article as:}

Archana V, S Thara Lakshmi. Preparation And Physico Chemical Analysis of A Herbomineral Rejuvenative Formulation- Lakshmi Vilasa Rasa. International Journal of Ayurveda and Pharma Research. 2021;9(12):11-18.

https://doi.org/10.47070/ijapr.v9i12.2172

\section{Source of support: Nil, Conflict of interest: None Declared}

11. Shastri K. Rasatarangini of Sadananda Sharma. 8th ed. New Delhi: Motilal Banarasidas Publication; 2014; pg no 318.

12. Shastri K. Rasatarangini of Sadananda Sharma. 8th ed. New Delhi: Motilal Banarasidas Publication; 2014; pg no 679.

13. Anonymous, The Ayurvedic Pharmacopoeia of India (API) (Ministry of Health and Family Welfare, Govt. of India, New Delhi) Part 2, Vol.4; The Controller of Publications, New Delhi, 2001; pg no 152.

14. Acharya R, Mitra S, Shukla V. Effect of Shodhana (processing) on Kupeelu (Strychnos nux-vomica Linn.) with special reference to strychnine and brucine content. AYU (An International Quarterly Journal of Research in Ayurveda). 2011; 32(3):402.

15. Abhishek A, BN A, K. S, Kumar S. Analytical evaluation of Mrityunjaya Rasa. Journal of Ayurveda and Integrated Medical Sciences (JAIMS). 2017; 2(06).

Disclaimer: IJAPR is solely owned by Mahadev Publications - dedicated to publish quality research, while every effort has been taken to verify the accuracy of the content published in our Journal. IJAPR cannot accept any responsibility or liability for the articles content which are published. The views expressed in articles by our contributing authors are not necessarily those of IJAPR editor or editorial board members.

*Address for correspondence Dr. Archana V

M.D Scholar,

Dept. of Rasa Sastra and

Bhaishajya Kalpana,

Government Ayurveda College,

Thiruvananthapuram, Kerala,

India.

Email: drarchanav11@gmail.com 